\title{
EFEKTIFITAS LARUTAN ALKALI PADA PROSES DEASETILASI DARI BERBAGAI BAHAN BAKU KITOSAN
}

\author{
Mursida $^{\star}$, Tasir, Sahriawati \\ Jurusan Teknologi Pengolahan Hasil Perikanan, Program Studi Teknologi Pengolahan Hasil Perikanan, \\ Politeknik Pertanian Negeri Pangkep \\ Jalan Poros Makassar Parepare Km.83. Kec.Mandalle Kab.Pangkep 90655 Sulawesi Selatan \\ Telepon (0410)2312703, 2312704 Fax. (0410)2312705 \\ ${ }^{\star}$ Korespondensi: labalekemursida@gmail.com \\ Diterima: 30 Oktober 2017/Disetujui: 25 Agustus 2018
}

Cara sitasi: Mursida, Tasir, Sahriawati. 2018. Efektifitas larutan alkali pada proses deasetilasi dari berbagai bahan baku kitosan. Jurnal Pengolahan Hasil Perikanan Indonesia. 21(2): 356-366.

\begin{abstract}
Abstrak
Bahan organik utama yang terdapat pada kelompok hewan crustaceae, insekta, fungi, moluska, arthropoda disebut kitin. Serbuk kitin dideasetilasi untuk memperoleh senyawa kitosan. Karakterisasi kitosan yang sangat penting adalah derajat deasetilasi (DD) yang tergantung pada jenis bahan baku dan proses produksinya. Deasetilasi merupakan proses penghilangan gugus asetil dengan cara penambahan larutan alkali. Efektifitas jenis alkali pada beberapa sumber perlu diteliti untuk mendapatkan kemurnian kitosan yang tinggi. Penelitian ini bertujuan untuk menentukan jenis alkali $\left(\mathrm{NaOH}, \mathrm{KOH}\right.$ dan $\left.\mathrm{CaOH}_{2}\right)$ yang paling efektif pada proses deasetilasi serbuk kitin serta menentukan karakteristik kitosan yang dihasilkan. Sumber kitin yang di deasetilasi dari cangkang kepiting bakau, cangkang rajungan, kulit udang windu, kulit udang vannamei, cangkang kerang hijau dan cangkang bekicot. Penelitian terdiri atas dua tahap, tahap pertama adalah preparasi bahan baku dan analisis kandungan kimia bahan baku, sedangkan tahap kedua yaitu produksi dan karakterisasi kitosan. Analisis yang dilakukan terdiri dari analisis kandungan kimia, derajat deasetilasi dan kadar $\mathrm{N}$ kitosan. Hasil penelitian menunjukan Karakteristik kitosan yang dihasilkan yaitu rendemen 4,25-28,43\%, abu 0,42-1,30\%, N-total 5,08-5,73\%, derajat deasetilasi 83,40 $83,45 \%$. $\mathrm{NaOH}$ merupakan alkali yang cenderung lebih baik memberikan derajat deasetilasi kitosan tertinggi dari masing-masing sumber bahan baku kitosan.
\end{abstract}

Kata kunci: Cangkang bekicot, kepiting bakau, kerang hijau, rajungan, kulit udang.

\section{Effectivity of Alkali Solvents in Deacetylation Process of Chitosan from Several Resources}

\begin{abstract}
The main organic ingredient found in animal groups of crustaceae, insects, fungi, molluscs, arthropods is called chitin. Chitin powder should be deacetylated in order to obtain chitosan compounds. The most important characterization of chitosan is the degree of deacetylation (DD), which might be depending on the type of raw material and the production process. Deacetylation is the process of removing acetyl groups using an alkaline solution. The effectiveness of various alkali types needs to be investigated to obtain high chitosan purity. This study was aimed to determine the type of alkaline solutions $\left(\mathrm{NaOH}, \mathrm{KOH}\right.$ and $\left.\mathrm{CaOH}_{2}\right)$ which is the most effective in chitin powder deacetylation process and to determine the characteristics of chitosan produced. Source of deacetylated chitin from mangrove crab shells, crab shells, tiger shrimp skin, vannamei shrimp skin, green shells and snail shells. The research consists of two stages, the first stage includes preparation of raw materials and analysis of chemical content of raw materials, while the second stage was the production and characterization of chitosan. The research analysis consisted of chemical content analysis, deacetylation degree and chitosan $\mathrm{N}$ content. The results showed that the characteristics of chitosan produced were yield ranging from $4.3 \%-28.5 \%$, ash $0.42 \%-1.30 \%$, N-total $5.08 \%-5.73 \%$, deacetylation degree $83.40 \%-83.45 \%, \mathrm{NaOH}$ is an alkali which tends to better provide the highest deacetylation degree of chitosan from each source of chitosan raw material.
\end{abstract}

Keywords: fish crabs, green mussels, mangrove crabs, shells snails, shrimp skin. 


\section{PENDAHULUAN}

Cangkang atau kulit dari eksoskeleton arthropoda (kepiting dan udang), insekta, alga, dinding sel fungi, dan yeast merupakan sumber kitin, namun sumber bahan baku yang sering digunakan untuk sintesis kitin adalah cangkang udang dan cangkang kepiting (Afriani et al. 2016). Ekspor kepiting (umumnya kaleng) sekitar 4.000 ton per tahun, dan menghasilkan hasil samping produksi yang banyak. Hasil samping berupa kepala, kulit, maupun kaki kepiting umumnya mencapai 25\%-50\% dari berat bahan baku, dan berpotensi diolah menjadi kitin (Trisnawati et al. 2013). Kandungan kitin pada kulit udang sekitar 20\%-50\% berat kering (Azhar et al. 2010).

Pemanfaatan limbah hasil perikanan menjadi kitosan bukan saja memberikan nilai tambah pada usaha pengolahan hasil perikanan, tetapi juga dapat menanggulangi masalah pencemaran lingkungan yang ditimbulkan, terutama masalah bau yang dikeluarkan serta estetika lingkungan yang kurang bagus. Limbah tersebut terdiri dari tiga komponen utama yaitu protein, kalsium carbonat dan kitin. Potensi limbah ini dapat diolah lebih lanjut menjadi senyawa polisakarida seperti kitin $\left[\left(\mathrm{C}_{8} \mathrm{H}_{13} \mathrm{NO}_{5}\right)_{n}\right]$ melalui pendekatan teknologi yang tepat. Kitin dapat diolah lebih lanjut menjadi kitosan $\left[\left(\mathrm{C}_{6} \mathrm{H}_{11} \mathrm{NO}_{4}\right)_{\mathrm{n}}\right]$ produk ini mempunyai sifat mudah terurai dan tidak mempunyai sifat beracun sehingga sangat ramah terhadap lingkungan. Kitin mempunyai struktur yang sama walaupun berasal dari sumber yang berbeda, tetapi asosiasinya dengan protein dan kalsium karbonat memiliki kadar yang berbeda (Azhar et al. 2010).

Kitin disintesis dengan cara menghilangkan dua komponen besar yaitu protein dan mineral. Penghilangan protein melalui deproteinasi, penghilangan mineral berupa kalsium karbonat melalui demineralisasi, selain itu juga sejumlah kecil pigmen dihilangkan melalui dekolorisasi (Younes dan Rinaudo 2015). Dua metode sintesis yang telah dilakukan untuk menghasilkan kitin murni yaitu secara enzimatis dan kimiawi. Metode enzimatis menggunakan enzim dari bakteri sedangkan secara kimiawi dengan penambahan senyawa asam dan basa (Afriani et al. 2016).

Deproteinisasi secara kimiawi yang telah dilakukan dengan menggunakan senyawa kimia antara lain $\mathrm{NaOH}, \mathrm{Na}_{2} \mathrm{CO}_{3}, \mathrm{NaHCO}_{3}$, $\mathrm{KOH}, \mathrm{K}_{2} \mathrm{C}_{2} \mathrm{O}_{3}, \mathrm{KOH}, \mathrm{K}_{2} \mathrm{CO}_{3}, \mathrm{Ca}(\mathrm{OH})_{2}, \mathrm{Na}_{2} \mathrm{SO}_{3}$, $\mathrm{NaHSO}_{3}, \mathrm{CaHSO}, \mathrm{Na}_{3} \mathrm{PO}_{4}$ dan $\mathrm{Na}_{2} \mathrm{~S} . \mathrm{NaOH}$ merupakan senyawa kimia yang paling banyak digunakan dengan rentang konsentrasi 0,125$5 \mathrm{M}$ (Younes et al. 2012). Mineral dihilangkan dengan cara pengasaman menggunakan $\mathrm{HCl}$ (Fernandez-Kim 2004). Proses pemisahan mineral ditunjukkan dengan terbentuknya gas $\mathrm{CO}_{2}$ berupa gelembung udara pada saat larutan $\mathrm{HCl}$ ditambahkan dengan cangkang terdeproteinasi (Afriani et al. 2016).

Kitin yang diperoleh dapat diubah menjadi kitosan dengan cara merubah gugus asetamida $\left(-\mathrm{NHCOCH}_{3}\right)$ pada kitin menjadi gugus amina $\left(-\mathrm{NH}_{2}\right)$. Kemurnian kitosan sangat ditentukan oleh derajat deasetilasi, semakin banyak gugus asetil yang dapat dihilangkan maka semakin tinggi nilai derajat deasetilasinya. Kitosan telah banyak dipelajari dan diaplikasikan oleh beberapa peneliti diantaranya mempelajari karakteristik kitosan dari kulit udang dan pemanfaatannya untuk pengolahan limbah cair perikanan (Ibrahim et al. 2009), kitosan dari cangkang bekicot dan pemanfaatannya sebagai adsorben logam berat seng ( $\mathrm{Zn}$ ) (Victor 2016), kitosan dari limbah cangkang kepiting sebagai bahan pengawet buah duku (Trisnawati 2013), karakterisasi dan aplikasi kitosan dari cangkang kerang hijau (Mytilus Viridis linneaus) sebagai koagulan penjernih air (Sinardi 2013), namun penelitian mengenai efektifitas jenis alkali dalam proses deasetilasi kitosan dari beberapa sumber belum pernah diteliti.

Efektifitas beberapa jenis larutan alkali atau basa kuat untuk merubah gugus asetamida $\left(-\mathrm{NHCOCH}_{3}\right)$ pada kitin menjadi gugus amina $\left(-\mathrm{NH}_{2}\right)$ pada beberapa bahan baku kitosan belum pernah dilaporkan. Berdasarkan hal tersebut, maka perlu dilakukan penelitian dalam proses deasetilasi kitin menjadi kitosan, selain konsentrasi alkali, suhu dan lama ekstraksi, faktor yang diduga berpengaruh terhadap karakteristik kitosan adalah jenis larutan alkali serta bahan 
baku kitosan yang digunakan. Tujuan dari penelitian adalah menentukan jenis larutan alkali yang paling efektif digunakan pada proses deasetilasi berdasarkan karakteristik kitosan dari beberapa bahan baku.

\section{BAHAN DAN METODE Bahan dan Alat}

Bahan yang digunakan dalam penelitian ini adalah kulit udang windu, kulit udang vannamei(PT. Bogatama Marinusa, Makassar), cangkang kepiting bakau, cangkang rajungan (PT. Phillips Seafood Indonesia, Barru), cangkang kerang hijau, dan cangkang bekicot (Masyarakat sekitar Kabupaten Pangkep), $\mathrm{HCl}$ (teknis), Akuades, $\mathrm{NaOH}$ (teknis), Aseton (teknis), $\mathrm{KOH}$ (teknis), $\mathrm{Ca}(\mathrm{OH})_{2}$ (teknis), asam asetat (pa Merck), $\mathrm{AgNO}_{3}$ (pa Merck), $\mathrm{H}_{2} \mathrm{SO}_{4}$ (pa Merck), $\mathrm{H}_{2} \mathrm{O}_{2}$ (pa Merck), $\mathrm{H}_{3} \mathrm{BO}_{3}$ (pa Merck), indikator MM dan BCG (pa Merck), selenium mixture (pa Merck), diperoleh dari toko bahan kimia CV. Intraco. Alat yang digunakan antara lain peralatan gelas (Pyrex), labu kjeldahl (Foss, Jerman), waterbath and shaker (Memmert, Jerman), neraca analitik (Sartorius, Jerman), oven (Memmert, Jerman), destruktion kjeltec unit (Foss, Jerman), destilation kjeltec unit (Foss, Jermn), furnace (Barnstead Thermolyne, Jerman), blender (Phillips, Indonesia).

\section{Metode Penelitian}

Penelitian ini dilakukan dalam dua tahap, tahap pendahuluan mencakup preparasi bahan baku kemudian dilakukan analisis kadar abu (BSN 2006), mineral kalsium (Rahmadani 2011) dan kadar protein (BSN 2006), tahap berikutnya yaitu produksi dan karakterisasi kitosan. Preparasi bahan baku berdasarkan hasil penelitian (Suharjo dan Harini 2005). Bahan baku direbus, kemudian dicuci dengan air agar kotoran yang melekat hilang, dikeringkan dalam oven pada suhu $110-120^{\circ} \mathrm{C}$ selama kurang lebih satu jam, setelah kering kemudian digiling atau di blender kering, diayak dengan ukuran 100 mesh.

\section{Ekstraksi kitosan}

Ekstraksi kitosan berdasarkan perlakuan terbaik hasil penelitian dari Sofia et al. (2010),
Puspawati dan Simpen (2010). Perolehan kitosan maksimum diperoleh dengan mode operasi DMPAK yaitu demineralisasi, deproteinasi, deasetilasi, dekolorisasi. Proses ekstraksi kitosan terdiri dari 3 tahap yakni proses penghilangan mineral, penghilangan protein dan deasetilasi.

Proses penghilangan mineral dilakukan dengan cara serbuk bahan baku ditimbang, kemudian ditambahkan $\mathrm{HCl}$ 1,5 M dengan perbandingan 1:15 (b/v) antara sampel dengan pelarut. Campuran dipanaskan pada suhu $70-120^{\circ} \mathrm{C}$ selama 4 jam sambil dilakukan pengadukan kemudian disaring. Padatan yang diperoleh dicuci dengan akuades untuk menghilangkan $\mathrm{HCl}$ yang tersisa. Filtrat terakhir yang diperoleh diuji dengan larutan $\mathrm{AgNO}_{3}$, bila sudah tidak terbentuk endapan putih maka sisa ion $\mathrm{Cl}$ yang terkandung sudah hilang, selanjutnya padatan dikeringkan pada oven dengan temperatur $70^{\circ} \mathrm{C}$ selama 24 jam sehingga diperoleh serbuk bahan tanpa mineral yang kemudian didinginkan dalam desikator.

Penghilangan protein (deproteinasi) dengan cara menambahkan larutan $\mathrm{NaOH} \quad 3,5 \%$ dengan perbandingan 1:10 (b/v) pada sampel yang sudah melewati tahap demineralisasi. Campuran tersebut dipanaskan pada suhu $65-70^{\circ} \mathrm{C}$ selama 2 jam sambil dilakukan pengadukan, padatan disaring dan didinginkan sehingga diperoleh kitin, yang kemudian dicuci dengan akuades sampai $\mathrm{pH}$ netral. Filtrat yang diperoleh diuji dengan pereaksi biuret, bila filtrat berubah menjadi biru berarti protein yang terkandung sudah hilang. Kitin yang terkandung pada sampel juga dapat dideteksi dengan reaksi warna Van Wesslink. Kitin direaksikan dengan larutan $\mathrm{I}_{2}$-KI $1 \%$ yang memberikan warna cokelat, kemudian jika ditambahkan $\mathrm{H}_{2} \mathrm{SO}_{4}$ $1 \mathrm{M}$ berubah menjadi violet, menunjukkan reaksi positif adanya kitin (Marganof 2003).

Proses deasetilasi dimodifikasi pada beberapa jenis alkali berdasarkan perlakuan konsentrasi 60\% dengan perbandingan 1:20 (b/v) antara kitin dengan pelarut. Campuran diaduk dan dipanaskan pada suhu $120^{\circ} \mathrm{C}$ selama 4 jam. Larutan dipisahkan dan disaring menggunakan kertas saring whatman, kemudian larutan dititrasi dengan $\mathrm{HCl} 7$ 
$\mathrm{N}$ untuk mengendapkan kembali kitosan, lalu disentrifugasi pada $2.000 \mathrm{rpm}$ selama 5 menit untuk memisahkan kitosan, kemudian endapan dipisahkan. Padatan dikeringkan pada $80^{\circ} \mathrm{C}$ selama 24 jam.

Pemurnian kitosan dilakukan dengan cara melarutkan kitosan dalam alkali (disesuaikan dengan tahap deasetilasi), sesuai dengan konsentrasi yang digunakan dalam tahap deasetilasi, larutan dipisahkan lalu dinetralkan dengan $\mathrm{HCl} 7 \mathrm{~N}$ sampai $\mathrm{pH}$ 7,0 untuk mengendapkan kembali kitosan, larutan disentrifugasi pada $2.000 \mathrm{rpm}$ selama 5 menit untuk memisahkan kitosan murni, supernatan dipisahkan dan endapan yang diperoleh dicuci dengan akuades, filtrat yang diperoleh diuji dengan larutan $\mathrm{AgNO}_{3}$, bila sudah tidak terbentuk endapan putih maka sisa ion $\mathrm{Cl}$ yang terkandung sudah hilang. Kemudian padatan dikeringkan pada suhu $80^{\circ} \mathrm{C}$ selama 24 jam. Pengujian kemurnian kitosan dilakukan dengan cara kitosan yang telah kering dilarutkan dalam larutan asam asetat $2 \%$ dengan perbandingan $1: 100(\mathrm{~b} / \mathrm{v})$ antara kitosan dengan pelarut. Kitosan dikatakan mempunyai kemurnian yang tinggi bila larut dalam larutan asam asetat $2 \%$ (Mukherjee 2001).

\section{Karakterisasi kitosan}

Rendemen kitosan

Rendemen dihitung dengan melakukan penimbangan kitosan yang telah dihasilkan, kemudian dibagi dengan berat bahan baku kering yang diproses mengacu pada metode (Purwanti 2014).

Rendemen $\%=\frac{\text { Massa kitosan kering }(g)}{\text { Massa bahan baku kering }(g)} \times 100$

\section{Kadar Abu dan Kadar N-Total}

Kadar abu dan kadar N-total (analisis kadar protein) ditentukan berdasarkan prosedur yang ditetapkan BSN (2006). Metode Kjeldahl digunakan untuk menganalisis kadar protein kasar dalam bahan makanan secara tidak langsung, karena yang dianalisis dengan cara ini adalah kadar nitrogennya, dengan mengalikan hasil analisis (N-total) tersebut dengan angka konversi diperoleh nilai protein dalam bahan, faktor konversi kadar $\mathrm{N}$ menjadi kadar protein untuk produk perikanan sebesar 6,25.

\section{Derajat Deasetilasi}

Derajat deasetilasi ditentukan dengan menggunakan metode titrasi asam basa (Purwanti 2014). Kitosan sebanyak 0,3 g dilarutkan ke dalam $30 \mathrm{~mL} \mathrm{HCl} 0,1 \mathrm{M}$. Indikator metil orange sebanyak 2 tetes ditambahkan ke dalam larutan tersebut. Sampel kemudian dititrasi menggunakan larutan $\mathrm{NaOH}$ 0,1M sampai terjadi perubahan warna. Perhitungan derajat deasetilasi dapat dilakukan dengan menggunakan persamaan 3 , sebagai berikut:

$$
\mathrm{DD} \%=\frac{(\mathrm{C} 1 \mathrm{~V} 1-\mathrm{C} 2 \mathrm{~V} 2)}{\mathrm{M} \times 0,994} \times 0,0016
$$

\section{Analisis Data}

Penelitian menggunakan rancangan acak lengkap factorial dengan dua factor perlakuan (beberapa sumber bahan baku dan jenis larutan alkali pada proses deasetilasi) dan 3 ulangan. Data yang diperoleh dari hasil pengamatan dianalisis secara deskriptif dan statistik dengan analisis sidik ragam (analysis of variance) menggunakan software SPSS 16. Bila hasil analisis sidik ragam memperlihatkan pengaruh nyata $(\alpha=0,05)$ maka dilakukan uji beda nyata dengan menggunakan uji lanjut Tukey. Penentuan jenis alkali terbaik yang dapat diterapkan pada proses deasetilasi kitosan dari masing-masing bahan baku yang digunakan.

\section{HASIL DAN PEMBAHASAN Komposisi Kimia}

Komposisi kimia sumber kitosan tergantung dari jenis dan habitatnya, Kadar protein dari ke-6 jenis bahan baku kitosan berkisar 10,22-38,00\% (Tabel 1). Kadar protein udang windu cenderung lebih tinggi dibandingkan dengan bahan baku lainnya, hasil yang diperoleh sesuai dengan hasil penelitian Wowor et al. (2015) limbah kulit udang mengandung protein kasar sekitar $25-40 \%$.

Protein pada kulit udang yang tinggi disebabkan kulit udang mengandung astaksantin. Klomklao etal. (2007) menyatakan bahwa astaksantin berikatan dengan protein karotenoid. Astaksantin merupakan jenis karotenoid yang banyak terkandung dalam 
Tabel 1 Komposisi kimia dalam basis kering beberapa sumber kitosan

(Table 1 Chemical composition in dry base several chitosan sources)

\begin{tabular}{lccc}
\hline \multirow{2}{*}{ Sumber kitosan/ Sources of chitosan } & \multicolumn{3}{c}{ Komposisi Kimia/ Chemical composition } \\
\cline { 2 - 4 } & $\begin{array}{l}\text { Kadar abu/ } \\
\text { Ash content } \\
(\% \mathrm{~b} / \mathrm{b})\end{array}$ & $\begin{array}{c}\text { Kadar protein/ } \\
\text { Protein content } \\
(\% \mathrm{~b} / \mathrm{b})\end{array}$ & $\begin{array}{c}\text { Kadar kalsium/ } \\
\text { Calcium content } \\
(\mathrm{mg} \mathrm{Ca} / 100 \mathrm{gr} \\
\text { material })\end{array}$ \\
\hline $\begin{array}{l}\text { Kulit udang windu/ Tiger shrimp skin } \\
\begin{array}{l}\text { Kulit udang vannamei/ Vannamei shrimp } \\
\text { skin }\end{array}\end{array}$ & $27.87 \pm 1.35^{\mathrm{a}}$ & $38.00 \pm 0.27^{\mathrm{a}}$ & $33.52 \pm 0.46^{\mathrm{a}}$ \\
$\begin{array}{l}\text { Cangkang kepiting bakau/ Shell of mangrove } \\
\text { crab }\end{array}$ & $74.22 \pm 1.00^{\mathrm{b}}$ & $17.28 \pm 0.41^{\mathrm{b}}$ & $39.76 \pm 0.13^{\mathrm{a}}$ \\
\hline
\end{tabular}

salmon dan krustasea dengan memberikan karakteristik warna merah muda pada salmon dan krustasea, selain astaksantin, tingginya protein pada udang karena udang merupakan sumber makanan yang kaya akan asam amino diantaranya asam glutamat, asam aspartat, arginina, lisina, leusina, glisina dan alanina. Kandungan asam amino pada udang berbeda tiap musim, sehingga musim mempengaruhi akumulasi asam amino dalam tubuh udang (Yanar et al. 2006). Kadar protein cangkang kepiting bakau $17,28 \%$ lebih tinggi dari hasil penelitian Humairah (2017) yaitu $14,11 \%$, kadar protein cangkang rajungan $19,34 \%$ lebih tinggi dari hasil penelitian Syukron et al. (2016) yaitu 15,39\%.

Kadar abu yang tinggi dari kulit dan cangkang dari berbagai bahan baku kitosan yang digunakan pada penelitian ini menunjukkan kandungan mineral yang sangat tinggi, kadar abu berkisar 27,87-78,64\%, kadar abu cangkang kerang hijau cenderung lebih tinggi dibandingkan dengan bahan baku lainnya. Kadar abu sumber kitosan berbanding lurus dengan kadar kalsium, semakin tinggi kadar abu semakin tinggi kadar mineral sumber kitosan, kadar abu menunjukkan besarnya kandungan mineral total masing-masing bahan. Mineral yang tinggi umumnya berbentuk kalsium karbonat $\left(\mathrm{CaCO}_{3}\right)$ dan sebagian kecil berbentuk kalsium fosfat $\mathrm{Ca}_{3}\left(\mathrm{PO}_{4}\right)_{2}$. Kadar kalsium ke-6 bahan baku kitosan berkisar dari 27,49$53,47 \%$. Kadar kalsium cangkang rajungan cenderung lebih tinggi dibandingkan dengan bahan baku lainnya. Kadar abu dari beberapa bahan baku kitosan pada penelitian ini lebih tinggi dari hasil penelitian Rochima (2007) yang menggunakan limbah kepiting yaitu $42,61 \%$. Mineral merupakan unsur pokok yang terdapat dalam eksoskeleton (berperan dalam pembentukan kulit dan karapas) (Zainuddin 2012).

\section{Karakteristik kitosan Rendemen}

Rendemen kitosan dipengaruhi oleh bahan baku dan proses produksinya. Menurut Tanasale (2010) semakin tinggi konsentrasi $\mathrm{NaOH}$ dan suhu yang digunakan pada proses deasetilasi, semakin tinggi pula nilai derajat deasetilasi sehingga mutu kitosan semakin tinggi pula, namun menurut Azhar et al. (2010) konsentrasi alkali dan suhu yang terlalu tinggi dapat menurunkan rendemen kitosan serta menyebabkan depolimerisasi dan degradasi polimer. Menurut Marganof (2003) rendemen kitin dari cangkang kepiting lebih sedikit dibandingkan kulit udang, karena kandungan mineral cangkang kepiting 53,70-78,40\% lebih besar dibandingkan dengan kandungan mineral kulit udang $45-50 \%$.

Ukuran partikel yang cukup kecil akan memperluas permukaan bahan, sehingga makin banyak gugus asetil yang dapat diikat oleh alkali selama proses ekstraksi namun rendemen kitosan yang semakin kecil tetapi kualitas kitosan yang lebih baik atau lebih murni dalam hal ini sudah banyak gugus asetil yang terlepas dari polimer kitin. Berdasarkan hasil penelitian diperoleh rendemen kitin dan 
kitosan dari berbagai sumber bahan baku dengan penggunaan tiga jenis alkali atau basa kuat pada proses deasetilasi disajikan pada Tabel 2.

Proses pemanasan yang semakin lama akan menyebabkan semakin banyak mineral yang tereliminasi yang menyebabkan berat kitin yang dihasilkan semakin kecil. Rendemen yang rendah pada setiap sumber bahan baku dikarenakan persentase mineral yang cukup tinggi berkisar 22,34-88,64\%. Senyawa kalsium akan bereaksi dengan asam klorida yang larut dalam air selama proses demineralisasi (Bastaman 1989). Proses pemisahan mineral terjadi dapat ditunjukkan dengan terbentuknya gas $\mathrm{CO}_{2}$ berupa gelembung udara pada saat $\mathrm{HCl}$ ditambahkan ke dalam sampel (Hendri 2008). Protein, lemak, fosfor, magnesium dan besi turut terbuang dalam proses demineralisasi (Rochima 2007).

Hasil analisis ragam menunjukkan perlakuan bahan baku, jenis alkali dan interaksi antara bahan baku dan jenis alkali memberikan pengaruh sangat nyata terhadap rendemen kitosan $(\mathrm{p}<0,05)$. Hasil uji lanjut Tukey menunjukkan perlakuan variasi bahan baku menghasilkan rendemen kitosan yang berbeda nyata pada beberapa perlakuan, rendemen yang dihasilkan dari perlakuan alkali $\mathrm{NaOH}$ tidak berbeda nyata dengan $\mathrm{KOH}$ tetapi berbeda nyata dengan $\mathrm{Ca}(\mathrm{OH})_{2}$. $\mathrm{KOH}$ dan $\mathrm{NaOH}$ memiliki kekuatan basa yang lebih tinggi dibandingkan alkali lainnya, sehingga memiliki kemampuan untuk mereduksi kitin menjadi kitosan lebih tinggi pula, rendemen kitosan yang dihasilkan lebih rendah, namun memiliki kualitas yang lebih baik. Hasil rendemen yang berbeda dari masing-masing perlakuan dipengaruhi oleh kandungan utama bahan baku, tingginya kadar protein dan mineral berupa kalsium karbonat mengakibatkan rendemen kitosan rendah, karena merupakan bagian yang hilang disamping pigmen dalam proses ekstraksi kitosan. Hasil yang diperoleh sesuai dengan penelitian yang dilakukan Marganof (2003) bahwa kandungan kitin pada kepiting berkisar $18,70-32,20 \%$. Rendemen kitosan yang tinggi dihasilkan dengan perlakuan alkali $\mathrm{Ca}(\mathrm{OH})_{2}$ karena sifatnya yang sedikit larut dalam air, sehingga menimbulkan endapan dan bercampur dengan kitosan.

\section{Kadar Abu}

Proses demineralisasi adalah tahapan perlakuan untuk menghilangkan $\mathrm{CaCO}_{3}$ dalam jumlah besar dan $\mathrm{Ca}_{3}\left(\mathrm{PO}_{4}\right)_{2}$ dalam jumlah kecil. Kandungan abu kitosan tanpa proses demineralisasi sangat tinggi. Nugroho et al. (2011) melaporkan bahwa kadar abu merupakan ukuran keberhasilan proses demineralisasi pada proses isolasi kitin dari bahan bakunya. No dan Meyers (1995) menyatakan bahwa kadar abu dapat berpengaruh terhadap kelarutan, serta dapat berkontribusi terhadap rendahnya viskositas, atau berpengaruh terhadap karakteristik produk akhir. Kualitas kitosan yang baik memiliiki kadar abu kurang dari $1 \%$. Kadar abu kitosan dengan perlakuan berbagai bahan baku dan jenis larutan alkali

Tabel 2 Rendemen kitin dan kitosan dari berbagai bahan baku dengan perlakuan alkali berbeda pada tahap deasetilasi

(Table 2 Yield of chitin and chitosan from various raw materials with different alkali treatments at the deacetylation stage)

\begin{tabular}{lccc}
\hline \multirow{2}{*}{$\begin{array}{c}\text { Sumber kitin dan kitosan/ Sources of chitin and } \\
\text { chitosan }\end{array}$} & \multicolumn{3}{c}{$\begin{array}{c}\text { Rendemen kitosan (\%b/b)/ } \\
\text { Chitosan yield (\%b/b) }\end{array}$} \\
\cline { 2 - 4 } & $\mathrm{KOH}$ & $\mathrm{Ca}(\mathrm{OH})_{2}$ & $\mathrm{NaOH}$ \\
\hline Kulit udang windu/ Tiger shrimp skin & $25.19 \pm 0.04^{\mathrm{a}}$ & $25.36 \pm 0.07^{\mathrm{b}}$ & $25.30 \pm 0.02^{\mathrm{a}}$ \\
Kulit udang vannamei/ Vannamei shrimp skin & $28.43 \pm 0.03^{\mathrm{b}}$ & $28.54 \pm 0.04^{\mathrm{a}}$ & $28.46 \pm 0.05^{\mathrm{b}}$ \\
Cangkang kepiting bakau/ Shell of mangrove crab & $11.63 \pm 0.03^{\mathrm{c}}$ & $11.71 \pm 0.01^{\mathrm{c}}$ & $11.63 \pm 0.03^{\mathrm{c}}$ \\
Cangkang rajungan/ Shellfish crabs & $9.95 \pm 0.11^{\mathrm{d}}$ & $10.10 \pm 0.02^{\mathrm{d}}$ & $10.21 \pm 0.16^{\mathrm{d}}$ \\
Cangkang kerang hijau/ Green shell shells & $4.25 \pm 0.05^{\mathrm{e}}$ & $4.32 \pm 0.03^{\mathrm{e}}$ & $4.26 \pm 0.01^{\mathrm{e}}$ \\
\hline
\end{tabular}


pada tahap deasetilasi disajikan pada Tabel 3.

Hasil analisis ragam menunjukkan perlakuan bahan baku,jenisalkali daninteraksi antara bahan baku dan alkali berpangaruh sangat nyata terhadap kadar abu kitosan $(\mathrm{p}<0,05)$. Hasil uji lanjut Tukey menunjukkan kadar abu kitosan pada perlakuan alkali $\mathrm{Ca}(\mathrm{OH})_{2}$ berbeda nyata dengan alkali lainnya namun kadar abu kitosan yang dihasilkan dari alkali $\mathrm{NaOH}$, dan $\mathrm{KOH}$ tidak berbeda nyata $(\mathrm{p}>0,05)$. Kelarutan $\mathrm{Ca}(\mathrm{OH})_{2}$ dalam air tidak sempurna, ion Ca dari alkali yang mengendap dengan kitosan dan mempengaruhi kadar abu kitosan, sehingga diperlukan proses pencucian yang sempurna. Proses demineralisasi dan proses deasetilasi juga diharapkan mampu menurunkan kadar abu sehingga diperoleh kadar abu kitosan lebih rendah dari kitin, yang bersumber dari berbagai bahan baku dan perlakuan jenis larutan alkali, kitosan yang dihasilkan memenuhi standar kadar abu menurut BSN (2013) kadar abu kitosan maksimal 5\%.

\section{Kadar N-Total}

Perbedaan kitin dan kitosan terletak pada kandungan nitrogennya, bila kandungan total nitrogennya kurang dari 7\%, maka polimer tersebut adalah kitin dan apabila kandungan total nitrogennya lebih dari 7\% maka disebut kitosan. Kadar N-Total kitosan dari hasil penelitian disajikan dalam Tabel 4 .

Efektifitas proses deproteinasi bergantung pada bahan bakunya. Hasil analisis ragam menunjukkan perlakuan bahan baku, jenis alkali dan interaksi antara bahan baku dan alkali berpangaruh sangat nyata terhadap kadar $\mathrm{N}$ kitosan $(\mathrm{p}<0,05)$. Hasil uji lanjut Tukey menunjukkan perlakuan bahan baku menghasilkan kadar $\mathrm{N}$ kitosan yang berbeda

Tabel 3 Keragaman kadar abu berbagai bahan baku dan perlakuan jenis alkali pada produk kitosan

(Table 3 Analysis diversity of ash content of various raw materials and alkali type treatment on chitosan products)

\begin{tabular}{lccc}
\hline \multirow{2}{*}{\multicolumn{1}{c}{ Sumber kitosan/ Sources of chitosan }} & \multicolumn{3}{c}{ Kadar abu kitosan (\%)/ Chitosan ash } \\
& content (\%) \\
\cline { 2 - 4 } & $\mathrm{KOH}$ & $\mathrm{Ca}\left(\mathrm{OH}_{2}\right)$ & $\mathrm{NaOH}$ \\
\hline Kulit udang windu/ Tiger shrimp skin & $0.52 \pm 0.02^{\mathrm{a}}$ & $0.77 \pm 0.02^{\mathrm{g}}$ & $0.52 \pm 0.02^{\mathrm{a}}$ \\
Kulit udang vannamei/ Vannamei shrimp skin & $0.42 \pm 0.02^{\mathrm{b}}$ & $0.48 \pm 0.03^{\mathrm{h}}$ & $0.42 \pm 0.04^{\mathrm{b}}$ \\
Cangkang kepiting bakau/ Shell of mangrove crab & $0.94 \pm 0.04^{\mathrm{c}}$ & $1.03 \pm 0.05^{\mathrm{i}}$ & $0.95 \pm 0.04^{\mathrm{c}}$ \\
Cangkang rajungan/ Shellfish crabs & $0.89 \pm 0.02^{\mathrm{d}}$ & $0.98 \pm 0.01^{\mathrm{j}}$ & $0.90 \pm 0.02^{\mathrm{d}}$ \\
Cangkang kerang hijau/ Green shell shells & $1.30 \pm 0.02^{\mathrm{e}}$ & $1.36 \pm 0.06^{\mathrm{k}}$ & $1.30 \pm 0.01^{\mathrm{e}}$ \\
\hline
\end{tabular}

Tabel 4 Hasil analisis keragaman kadar N-total berbagai bahan baku dan perlakuan jenis alkali pada produk kitosan

(Table 4 Result of analysis of the diversity of $N$-total content of various raw materials and alkali type treatment on chitosan products)

\begin{tabular}{lccc}
\hline \multirow{2}{*}{\multicolumn{1}{c}{ Sumber kitosan/ Sources of chitosan }} & \multicolumn{3}{c}{ Kadar N-total kitosan (\%)/ Chitosan } \\
& \multicolumn{3}{c}{ N-total content (\%) } \\
\cline { 2 - 4 } & $\mathrm{KOH}$ & $\mathrm{Ca}\left(\mathrm{OH}_{2}\right)$ & $\mathrm{NaOH}$ \\
\hline Kulit udang windu/ Tiger shrimp skin & $5.71 \pm 0.03^{\mathrm{a}}$ & $6.24 \pm 0.04^{\mathrm{g}}$ & $5.73 \pm 0.03^{\mathrm{a}}$ \\
Kulit udang vannamei/ Vannamei shrimp skin & $5.32 \pm 0.03^{\mathrm{b}}$ & $5.70 \pm 0.03^{\mathrm{h}}$ & $5.32 \pm 0.02^{\mathrm{b}}$ \\
Cangkang kepiting bakau/ Shell of mangrove crab & $5.22 \pm 0.02^{\mathrm{c}}$ & $5.23 \pm 0.03^{\mathrm{c}}$ & $5.22 \pm 0.02^{\mathrm{c}}$ \\
Cangkang rajungan/ Shellfish crabs & $5.26 \pm 0.03^{\mathrm{d}}$ & $5.35 \pm 0.02^{\mathrm{i}}$ & $5.29 \pm 0.01^{\mathrm{d}}$ \\
Cangkang kerang hijau/ Green shell shells & $5.09 \pm 0.03^{\mathrm{e}}$ & $5.15 \pm 0.03^{\mathrm{j}}$ & $5.08 \pm 0.01^{\mathrm{e}}$ \\
Cangkang bekicot/ Snails shell & $5.15 \pm 0.05^{\mathrm{f}}$ & $5.20 \pm 0.01^{\mathrm{k}}$ & $5.14 \pm 0.07^{\mathrm{f}}$ \\
\hline
\end{tabular}


nyata antar bahan baku lain yang digunakan $(\mathrm{p}<0,05)$, kadar $\mathrm{N}$ kitosan yang dihasilkan dari jenis alkali $\mathrm{KOH}$ tidak berbeda nyata dengan $\mathrm{NaOH}$ namun berbeda nyata dengan $\mathrm{Ca}(\mathrm{OH})_{2} \quad(\mathrm{p}<0,05) . \quad \mathrm{NaOH}$ lebih sering digunakan karena relatif murah dan mudah didapatkan. Proses deasetilasi diharapkan mampu menurunkan kadar $\mathrm{N}$-total selain dari proses deproteinasi, sehingga diperoleh kadar $\mathrm{N}$-total kitosan lebih rendah dari kitin. Kadar $\mathrm{N}$-total kitosan pada penelitian mendekati standar mutu yang ditetapkan. Menurut Protan (1987) biopolimer standar mutu kadar nitrogen kitosan yang telah ditetapkan adalah $\leq 5 \%$.

\section{Derajat Deasetilasi (DD)}

Deasetilasi merupakan proses penghilangan gugus asetil. Proses deasetilasi bertujuan untuk memutuskan ikatan kovalen antara gugus asetil dengan nitrogen pada gugus asetamida kitin menghasilkan gugus amina terdeasetilasi. Penghilangan gugus asetil yang besar pada gugus asetamida kitin dikenal dengan istilah derajat deasetilasi (DD). Proses deasetilasi kitin dapat dilakukan dengan cara memanaskan kitin dalam larutan basa kuat (Bastaman 1989). Derajat deasetilasi kitosan dari hasil penelitian dengan perlakuan berbagai sumber bahan baku dan jenis larutan alkali pada tahap deasetilasi dapat dilihat pada Tabel 5.

Hasil analisis ragam menunjukkan perlakuan jenis alkali berpengaruh sangat nyata terhadap DD kitosan, namun perlakuan bahan baku dan interaksi antara bahan baku dan alkali berpangaruh tidak nyata terhadap kadar DD kitosan $(\mathrm{p}>0,05)$. Hasil uji lanjut Tukey menunjukkan DD kitosan dari $\mathrm{KOH}$ dan $\mathrm{NaOH}$ berbeda nyata dengan $\mathrm{Ca}(\mathrm{OH})_{2}$. Derajat deasetilasi (DD) menunjukkan banyaknya gugus amino bebas dalam polisakarida kitosan. DD kitosan cenderung lebih tinggi pada perlakuan alkali NaOH. Menurut Azhar et al. (2010), konsentrasi ion $\mathrm{OH}^{-}$berhubungan dengan proses pelepasan gugus asetil dari gugus asetamida kitin. Konsentrasi $\mathrm{OH}^{-}$akan lebih besar pada larutan basa kuat. Kekuatan basa yang semakin besar maka semakin besar konsentrasi $\mathrm{OH}^{-}$dalam larutannya, sehingga kekuatan basa dapat mempengaruhi proses deasetilasi. Kemampuan ion hidrogen dari $\mathrm{Ca}(\mathrm{OH})_{2}$ lebih rendah dalam mensubtitusi gugus asetil pada kitin menjadi gugus amino dibandingkan dengan $\mathrm{NaOH}$ dan $\mathrm{KOH}$, dan menghasilkan DD yang lebih rendah. Ernawati (2008) menyatakan bahwa kualitas kitosan ditentukan berdasarkan derajat deasetilasinya sehingga dapat dibagi menjadi empat kriteria yang lebih kecil dari $80 \%$, antara $80-85 \%$, antara $85-90 \%$ dan di atas $90 \%$ (Ernawati 2008). DD kitosan yang dihasilkan dengan $\mathrm{NaOH}$ dan $\mathrm{KOH}$ antara $80-85 \%$, sedangkan penggunaan alkali $\mathrm{Ca}(\mathrm{OH})_{2}$ dihasilkan DD kitosan lebih kecil dari 80\%.

Kualitas kitosan dapat dilihat dari kadar air dan kadar abu yang rendah, tetapi memiliki derajat deasetilasi yang tinggi. Derajat deasetilasi semakin tinggi maka

Tabel 5 Hasil analisis keragaman derajat deasetilasi (\%) berbagai bahan baku dan perlakuan jenis alkali pada produk kitosan

(Table 5 Result of analysis of deacetylation degree diversity (\%) of various raw materials and alkali type treatment on chitosan products)

\begin{tabular}{lccc}
\hline \multirow{2}{*}{ Sumber kitosan/ Sources of chitosan } & \multicolumn{3}{c}{$\begin{array}{c}\text { Derajat deasetilasi kitosan (\%)/ Degree of } \\
\text { deacetylation of chitosan (\%) }\end{array}$} \\
& $\mathrm{KOH}$ & $\mathrm{Ca}(\mathrm{OH})_{2}$ & $\mathrm{NaOH}$ \\
\hline Kulit udang windu/ Tiger shrimp skin & $83.33 \pm 0.28^{\mathrm{a}}$ & $78.71 \pm 0.13^{\mathrm{b}}$ & $83.42 \pm 0.14^{\mathrm{a}}$ \\
Kulit udang vannamei/ Vannamei shrimp skin & $83.32 \pm 0.06^{\mathrm{a}}$ & $78.71 \pm 0.13^{\mathrm{b}}$ & $83.42 \pm 0.20^{\mathrm{a}}$ \\
Cangkang kepiting bakau/ Shell of mangrove crab & $83.30 \pm 0.08^{\mathrm{a}}$ & $78.71 \pm 0.13^{\mathrm{b}}$ & $83.42 \pm 0.14^{\mathrm{a}}$ \\
Cangkang rajungan/ Shellfish crabs & $83.23 \pm 0.14^{\mathrm{a}}$ & $78.65 \pm 0.05^{\mathrm{b}}$ & $83.40 \pm 0.10^{\mathrm{a}}$ \\
Cangkang kerang hijau/ Green shell shells & $83.25 \pm 0.04^{\mathrm{a}}$ & $78.62 \pm 0.10^{\mathrm{b}}$ & $83.45 \pm 0.19^{\mathrm{a}}$ \\
Cangkang bekicot/ Snail's shell & $83.36 \pm 0.23^{\mathrm{a}}$ & $78.66 \pm 0.14^{\mathrm{b}}$ & $83.40 \pm 0.21^{\mathrm{a}}$ \\
\hline
\end{tabular}


semakin banyak gugus amino $\left(\mathrm{NH}_{2}\right)$ pada molekul kitosan sehingga kitosan semakin reaktif. Derajat deasetilasi kitosan yang dihasilkan berkisar 78,62-83,42\% lebih baik dari hasil penelitian yang dilakukan Azhar et al. (2010) yaitu 65,3\%. Perbedaan tersebut disebabkan oleh perbedaan konsentrasi yang digunakan. Derajat deasetilasi kitosan yang diperoleh rata-rata $80 \%$, hal ini tergantung dari cara pengolahannya serta jenis cangkang yang digunakan (No dan Meyers 1995). Menurut Ramadhan et al. (2010) umumnya kitosan mempunyai derajat deasetilasi 75$100 \%$.

\section{KESIMPULAN}

Jenis larutan alkali $\mathrm{NaOH}$ dan $\mathrm{KOH}$ tidak berpengaruh nyata terhadap karakteristik kitosan dari berbagai bahan baku serta memenuhi standar mutu kitosan, namun berpengaruh terhadap DD. $\mathrm{NaOH}$ merupakan alkali terbaik yang memberikan dd kitosan tertinggi. Karakteristik kitosan yaitu rendemen berkisar dari 4,25-28,43\%, abu $0,42-1,30 \%$, $\mathrm{N}$-total 5,08-5,73\%, derajat deasetilasi 83,40-83,45\%.

\section{DAFTAR PUSTAKA}

Afriani Y, Fadli A, Maulana S, Karina I. 2016. Sintesis, Kinetika reaksi dan aplikasi kitin dari cangkang udang: Paper Conference, Review, (October). Universitas Riau. Pekanbaru Riau.

Azhar M, Efendi J, Syofyeni E, Lesi RM, Novalina S. (2010). Pengaruh konsentrasi $\mathrm{NaOH}$ dan $\mathrm{KOH}$ terhadap derajat deasetilasi kitin dari kulit udang. Eksakta. 1(11): 1-8.

Bastaman. 1989. Studies on degradation and extraction of chitin and chitosan from prawn shells. England (UK): The Queen University of Belfast.

[BSN] Badan Standardisasi Nasional. 2006. SNI-01-2354.1-2006. Penentuan kadar abu pada produk perikanan. Jakarta(ID): Badan Standarisasi Nasional.

[BSN] Badan Standardisasi Nasional. 2006. SNI-01-01-2354.4-2006. Penentuan kadar protein dengan metode total nitrogen pada produk perikanan. Jakarta (ID): Badan Standarisasi Nasional.
[BSN] Badan Standardisasi Nasional. 2013. SNI 7949-2013. Kitosan-syarat mutu dan pengolahan. Jakarta(ID): Badan Standarisasi Nasional.

Ernawati PT. 2008. Transformasi kitin menjadi chitosan dari limbah kulit udang dan cangkang kepiting serta aplikasinya sebagai biomaterial antibakteri dan potensinya sebagai antikanker. [Skripsi]. Bali (ID): Universitas Udayana

Fernandez-Kim, S-O. 2004. Physicochemical and functional properties of crawfish chitosan as affected by different processing protocols. [Tesis]. Seoul (KOR): Department of Food Science Seoul National University.

Hendri J. 2008. Teknik deproteinasi kulit rajungan (Portunus pelagious) secara enzimatik dengan menggunakan bakteri Pseudomonas aeruginosa untuk pembuatan polimer kitin dan deasetilasinya. Seminar Hasil Penelitian dan Pengabdian pada Masyarakat, Unila: 271-283.

Humairah S. 2017. Komposisi kimia cangkang kepiting bakau (Scylla serrata). [Skripsi]. Pekanbaru (ID): Universitas Riau.

Ibrahim B, Suptijah P, Prantommy. 2009. Pemanfaatan kitosan pada pengolahan limbah cair industri perikanan. Jurnal Pengolahan Hasil Perikanan. 12(2): 154-166.

Klomklao S, Benjakul S, Visessanguan W, Kishimura H, Simpson KB. 2007. Extraction of carotenoprotein from black tiger shrimp shells with the aid of bluefish trypsin. Thailand. Journal of Food Biochemistry. 201-217.

Marganof. 2003. Potensi limbah udang sebagai penjerat logam berat (timbal, kadmium, dan tembaga (http://www.rudyct.com/ PPS702-ipb/07134/marganof.pdf) dikunjkungi pada 15 Juni 2016.

Mukherjee, Debi P. 2001. Method for producing chitin or chitosan, $h t t p: / / w w w$. Freepatents online.com $/ 6310188 . \mathrm{htm}$. (7 Januari 2009).

Nugroho CSA, Nurhayati ND, Utami B. 2011. Sintesis dan karakterisasi membrane kitosan untuk aplikasi sensor deteksi logam berat. Molekul. 6(2): 123 -136. 
Purwanti A. 2014. Evaluasi proses pengolahan limbah kulit udang untuk meningkatkan mutu kitosan yang dihasilkan. Jurnal Teknologi. 7(1): 83-90

No HK, Lee MY. 1995. Isolation of chitin from crab shell waste. Journal Korean Soc. Food Nutrition. 24(1): 105-113.

No HK dan Meyers SP. 1995. Preparation and characcterization of chitin and chitosan-a review. Journal of Aquatic Food Product Technology. 42(2): 27-52.

Protan Laboratories. 1987. Catioal Polymer for Recovering Valuable by Products from Processing Waste Burgges. USA

Puspawati MN, Simpen NI. 2010. Optimasi deasetilasi khitin dari kulit udang dan cangkang kepiting limbah restoran seafood menjadi khitosan melalui variasi konsentrasi $\mathrm{NaOH}$. Jurnal Kimia. 4(1): 79-90.

Rahmadani S. 2011. Penentuan kadar kalsium dengan metode permanganometri terhadap tempe yang dibungkus plastik dan daun di pasar arengka pekanbaru. [Skripsi]. Pekanbaru (ID): Universitas Islam Negeri Sultan Syarif Kasim Riau.

Ramadhan LOAN, Radiman CL, Wahyuningrum D. 2010. Deasetilasi kitin secara bertahap dan pengaruhnya terhadap derajat deasetilasi serta massa molekul kitosan. Jurnal kimia Indonesia. 5(10): 17-21.

Rochima E. 2007. Karakterisasi kitin dan kitosan asal limbah rajungan cirebon jawa barat. Buletin Teknologi Hasil Perikanan. 10(1): 9-22.

Rochima E. 2014. Kajian pemanfaatan limbah rajungan dan aplikasinya untuk bahan minuman kesehatan berbasis kitosan. Study of utilization of crabs processing wastes and its application for chitosanbased healthy drink. Jurnal akuatika. 5(1): 71-82.

Sinardi, Soewondo P, Notodarmojo S. 2013. Pembuatan, karakterisasi dan aplikasi kitosan dari cangkang kerang hijau (Mytilus virdis linneaus) sebagai koagulan penjernih air. Universitas Sebelas Maret. Prosiding Konferensi Nasional Teknik Sipil 7. 2: 33-38.
Sofia I, Pirman, Haris Z. 2010. Karakterisasi fisikokimia dan fungsional kitosan yang diperoleh dari limbah cangkang udang windu. Jurnal Teknik Kimia Indonesia. 9(1): 11-18.

Suharjo dan Harini N. 2005. Ekstraksi chitosan dari cangkang udang windu (Penaeus monodon sp.) secara fisika-kimia (kajian berdasarkan ukuran partikel, tepung chitin dan konsentrasi $\mathrm{NaOH}$ ). Gamma. 1(1): 7-15.

Syukron F, Karnila R, Hasan B. 2016. Karakteristik glukosamin hidroklorida $(\mathrm{HCl} \mathrm{GlcN})$ dari kitin dan kepiting chitosan biru kolam (Portunus pelagicus). Berkala Perikanan Terubuk. 44(2): 22-35

Tanasale M. 2010. Kitosan berderajat deasetilasi tinggi: proses dan karakterisasi. Seminar Nasional Basic Science. 2: 187-193.

Trisnawati E, Andesti D, Saleh A. 2013. Pembuatan kitosan dari limbah cangkang kepiting sebagai bahan pengawet buah duku dengan variasi lama pengawetan. Jurnal Teknik Kimia. 9(2): 17-26.

Victor S, Andika B, dan Syauqiah I. 2016. Pemanfaatan kitosan dari limbah bekicot (Achatina fuica) sebagai adsorben logam berat seng ( $\mathrm{Zn}$ ). Konversi. 1(5): 22-26.

Wowor ARY, Bagau B, Untu I, Liwe H. 2015. Kandungan protein kasar, kalsium dan fosfor tepung limbah udang sebagai bahan pakan yang diolah dengan asam asetat $\left(\mathrm{CH}_{3} \mathrm{COOH}\right)$. Jurnal Zootek. 35(1): 1-9.

Yanar Y, Gocer M, Kucukgulmez A. 2011. Differences in nutritional composition between cultured and wild green tiger shrimp (Penaeus semisulcatus). Italian Journal food science. 23: 1-6.

Younes I, Ghorbel-Bellaaj O, Nasri R, Chaabouni M, Rianudo M, Nasri M. 2012. Chitin and chitosan preparation from shrimp shells using optimized enzymatic deproteinization. Proces Biochemistry. 47(12): 2032-2039.

Younes I, Rinaudo M. 2015. Chitin and chitosan preparation from marine sources. Structure, properties and applications. Journal Marine Drugs. 13(3): 1133-1174. 
Zainuddin. 2012. Efek Calsium-fosfor dengan rasio berbeda terhadap retensi nutrien dan perubahan komposisi kimia tubuh juvenil udang windu (Penaeus monodon Fabr). Jurnal Ilmu dan Teknologi Kelautan Tropis. 4(2): 208-216. 